\title{
The Effect of Leadership Style and Workload on Work Stress at Pt Bank Perkreditan Rakyat Buana Agribisnis Saribudolok
}

\section{Winka Putri Simanjorang1*, Caecilia Tri Wahyanti ${ }^{2}$}

1,2 Universitas Kristen Satya Wacana, Salatiga, Indonesia

\section{ART ICLE INFO}

\section{Article history:}

Received September 01, 2021

Revised September 03, 2021

Accepted October 13, 2021

Available online November 25, 2021

Keywords:

Leadership Style, Workload, Work Stress

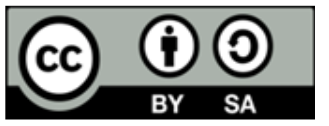

This is an open access article under the CC BY-SA license.

Copyright $(2021$ by Author. Published by Universitas Pendidikan Ganesha.

\begin{abstract}
A B S T RA C T
Workers find it difficult because the implementation of WFH has resulted in an increase in their workload and a workload that is not in accordance with their abilities. Worker. This causes work fatigue from mild to severe levels. The purpose of this study was to determine the effect of leadership style and workload on work stress, this type of research is quantitative research involving 35 respondents at PT Bank Perkreditan Rakyat Buana Agribisnis Saribudolok. The sampling technique used was non-probability sampling with a saturated sampling technique (census). because the population is small and the saturated sampling technique is a sampling technique when all members of the population are used as a sample of 35 people. The type of data used in this study is primary data which data directly provides to data collectors through questionnaires, and secondary data is data that is not obtained directly by researchers but is obtained from other people or parties. Data analysis used quantitative descriptive analysis techniques. The results show that leadership style is related to how employees guess the leadership style whether they like it or not. Bad leadership style causes employees to be unproductive and less creative so that it has an impact on career achievement so that employees are stressed with their work, while excessive workloads and short deadlines also greatly affect employee work stress. employees should be in accordance with the field and ability. So it can be said that the workload is a source of stress that affects the working conditions of employees.
\end{abstract}

\section{INTRODUCTION}

Humans are often known as social beings, incapable of surviving without the assistance of others. That is why humans like to live in organizations; evidence of this can be found in everyday life in society and even in the world of work (Charoensukmongkol, 2022; Gishti, 2018; Neill \& Bowen, 2021). For companies, human resources are very important to have, because the success of the organization is determined by the human element (Battisti et al., 2022; Dang-Pham et al., 2022; Jain et al., 2021). Therefore, in companies, human resource factors seen from employee performance are required to increase. In every organizational resource or its role contributes to achieving organizational goals efficiently and effectively in Human Resources (Ifeoma Obidile, 2018; Indiyaningsih et al., 2020). PT Bank Perkreditan Rakyat Buana Agribisnis Saribudolok which operates around Silimakuta District, Simalungun Regency is here to take part in encouraging human resource development through improving the economic sector, which is mainly directed at the businesses of small communities/low economic groups. In other words, to help local community businesses through capital assistance and generate rural community production businesses and also to introduce and give a banking touch to community businesses, especially micro businesses, small businesses and low-income groups (Hasna, 2019; Mahriani, 2018; Purwatiningsih \& Pornamasari, 2020). Where we know that there are still many micro-enterprises for agriculture and animal husbandry that have not been touched by either microfinance institutions or banks. With the presence of PT Bank Perkreditan Rakyat Buana Agribisnis Saribudolok is expected to increase capital which will automatically increase the income and welfare of the people in the Simalungun area. Bank Perkreditan Rakyat Buana Agribisnis is able to provide credit to the public at low interest rates and with easy collateral. So that the people in the Simalungun area who are predominantly farmers and have low education have no difficulty in fulfilling the administration and requirements to borrow money at the Bank Perkreditan Rakyat Buana Agribisnis located in Saribudolok, Silimakuta District, Simalungun Regency. 
Workload is a process to determine the number of working hours people use or need to complete a job within a certain time, or in other words workload analysis aims to determine how many personnel and how many responsibilities or workloads are appropriate to delegate to an employee (Abbasi et al., 2022; Bonfim et al., 2021; Esteban et al., 2022). The phenomenon observed by the researchers was work stress experienced by employees at PT Bank Perkreditan Rakyat Buana Agribisnis Saribudolok. Currently, Indonesia is facing the Covid-19 disaster. As a result of this covid 19, there are many obstacles faced by every employee at PT Bank Perkreditan Rakyat Buana Agribisnis, the obstacles faced include the large number of prospective customers or customers who cannot come directly to the bank to interact directly with the parties at the bank, resulting in better performance. slowed down and for some time in the future due to the increasing covid caused by some employees carrying out Work From Home (WFH) activities which automatically increase the workload of employees because they interact with customers via telephone, the obstacle that is often faced is the difficulty of prospective customers or customers to pick up telephone from the company so that the greater the workload that is borne by each employee. In a preresearch interview in August 2021 with one of the employees of PT Bank Perkreditan Rakyat Buana Agribisnis Saribudolok said that they found it difficult because of the implementation of $W F H$ which resulted in their workload increasing and workloads that were not in accordance with the ability of workers, causing work fatigue from mild to severe levels. The problem faced in work stress is when a customer or customer demands a lot from the employee, one of which is when the employee deals with customers who are too demanding, while employees must always deal with them politely, calmly and friendly. As a result of the great work pressure faced by each employee, it causes high work stress so that the physical condition of each employee will have a bad effect as well.

The leadership style of superiors is needed in a company. Leadership is a process of influencing the activities of each group or individual to achieve goals (Ariyani, 2021; Sergeeva \& Kortantamer, 2021; Sufriadi, 2019). Increased work stress often occurs because of superior behavior or leadership style. Leadership style is a leader's way of influencing the behavior and thoughts of subordinates in order to carry out their duties (Sufriadi, 2019)(Ariyani, 2021; Grigoropoulos, 2019; Sergeeva \& Kortantamer, 2021). A bad leadership style has an impact on employees being less creative and unproductive so that the desired career is not achieved by employees and causes employees to feel stressed about their work (AlNuaimi et al., 2021; Stremersch et al., 2021). In the other hand, the impact of a bad leadership style is work stress. Stress is an emotional pressure experienced by someone who is faced with great demands and obstacles that affect a person's physical, mental and emotional condition (Heinbockel et al., 2021; Klatzkin et al., 2022). Stress occurs when a person is experiencing a heavy task or burden where the employee cannot cope with the burden, then the body will not respond well to the task, causing stress (Schaper \& Stengel, 2022; Seo et al., 2021).

One of the causes of stress is a workload that is too heavy (McDonnell et al., 2021; Zhou et al., 2022). Giving the workload is the duty of every institution that will be given to employees should be in accordance with the fields and abilities (Bitkina et al., 2021; Chen \& Tserng, 2022; Verstappen et al., 2022). Therefore, it can be said that the workload is a source of stress that affects the working conditions of employees. From some of the definitions above, it can be concluded that stress occurs because personality characteristics and work aspects are not balanced. Excessive workload can cause employees to experience work stress and also as an obstacle in the company (Fazal et al., 2022; Li et al., 2020; Oludayo et al., 2018). Excessive workload causes tension in a person, causing stress. This is because the speed of work is required to be fast, the expertise required is too high and there are many jobs to do. Workload is a condition when faced with a task that must be completed at a certain time. Another category of workload is a combination of qualitative and quantitative workloads. Qualitative workload is when employees feel they are unable to complete their tasks or do not use their potential and skills. While quantitative workload is arising from too many or few tasks (Gibbs et al., 2021; Ogu et al., 2017). The objective of this study is to find out how much influence leadership style has on work stress, how much influence workload has on work stress, and how much influence leadership style and workload have on work stress.

\section{METHODS}

This research approach is based on a quantitative approach. Quantitative research is a research model using numbers as statistical results to be tested (Sugiyono, 2017). The population in this study were employees of PT Bank Perkreditan Rakyat Buana Agribisnis, totaling 35 people, including leaders an employees. The sample is part of the existing population, so that sampling must use a certain method based on existing considerations (Sugiyono, 2017). The sampling technique used in this study is non-probability sampling with a saturated sampling technique (census) because the population is small and the saturated sampling technique is a sampling technique when all members of the population are used as a sample of 35 
people. According to the type of data used in this study, namely the type of quantitative data. Sources of data in this study consisted of primary data and secondary data. Primary data is a data source that directly provides data to data collectors. Secondary data is data that is not obtained directly by researchers but is obtained from other parties. This study uses multiple linear regression analysis. Multiple linear regression to test the effect of one or more dependent variables. This study aims to determine the effect of the independent variable (leadership style and workload) on the dependent variable (work stress). The coefficient of determination $\left(R^{2}\right)$ essentially measures how far the model's ability to explain variations in the dependent variable is. The value of the coefficient of determination is between no and one. A small value of R2 means that the ability of the independent variables in explaining the variation of the dependent variable is very limited. A value close to one means that the independent variables provide almost all the information needed to predict the variation of the dependent variable. The F statistical test basically shows whether all independent or independent variables included in the model have a joint effect on the dependent variable. The t-statistic test basically shows how far the influence of an individual explanatory/independent variable in explaining the variation of the dependent variable.

\section{RESULTS AND DISCUSSIONS}

\section{Results}

The questionnaires distributed to respondents amounted to 35 questionnaires containing 27 questions in each questionnaire. This study used a percentage analysis based on the results of the questionnaire answers totaling 35 respondents consisting of gender, age and length of work. Respondents based on male respondents as many as 20 people and female respondents as many as 15 people, based on the age of respondents aged 23-27 as many as 10 people, respondents aged 27-31 as many as 12 people, respondents aged 31-35 as many as 8 people, respondents aged more than 35 years as many as 5 people, respondents based on length of work between $0-\leq 1$ year as many as 7 people, respondents who have worked between $1-\leq 2$ years as many as 15 people, and for $\geq 2$ years as many as 13 respondent. To find out the feasibility of the number in the list of questions that have been presented to the respondents, it is necessary to do a validity test. It can be said to be valid if $r_{\text {statictic }}>$ from $r_{\text {table }}$ or the validity of each question is greater than 0.30 then the data can be said to be valid. The value of $r_{\text {statistic }}$ is greater than 0,30 then the data on the leadership style variable is said to be valid, and the validity value is in the corrected item-Total column, which means the correlation value between the scores of each item and the total score in the respondent's answer table. So that the data obtained is also feasible to be used for further testing, namely reliability. The value of $r_{\text {statistic }}$ is greater than 0.30 then the data on the workload variable is said to be valid, and the validity value is in the corrected item-Total column, which means the correlation value between the scores of each item and the total score in the respondent's answer table. So that the data obtained is also feasible to be used for further testing, namely reliability.

The value of $r_{\text {statistic }}$ is greater than 0.30 then the data on the work stress variable is said to be valid, and the validity value is in the corrected item-Total column, which means the correlation value between the scores of each item and the total score in the respondent's answer table. So that the data obtained is also feasible to be used for further testing, namely reliability. Reliability tests can be carried out jointly on all questions, or individually for each question item. If the value of Cronbach's alpha $>0.6$, it is mean that the question item is reliable or reliable. The results of the SPSS output, it is known that the Cronbach's alpha value is $0.911>0.60$ so it can be concluded that the questions that have been given to respondents consisting of 9 questions on the leadership style variable (X1) are reliable or can be said to be reliable. The results of the SPSS output, it is known that the Cronbach's alpha value is $0.885>0.60$ so it can be concluded that the questions that have been given to respondents consisting of 10 questions on the workload variable (X2) are reliable or can be said to be reliable. The results of the SPSS output are known that the Cronbach's alpha value is $0.816>0.60$ so it can be concluded that the questions that have been given to respondents consisting of 8 questions on the work stress variable $(\mathrm{Y})$ are reliable or can be said to be reliable. The normality test intends to obtain the distribution of the data in the variables that will be used in the study. Following are the results of the normality test using histogram graph analysis, Probability-Plot and Kolmogorov-Smirnov statistical analysis. 


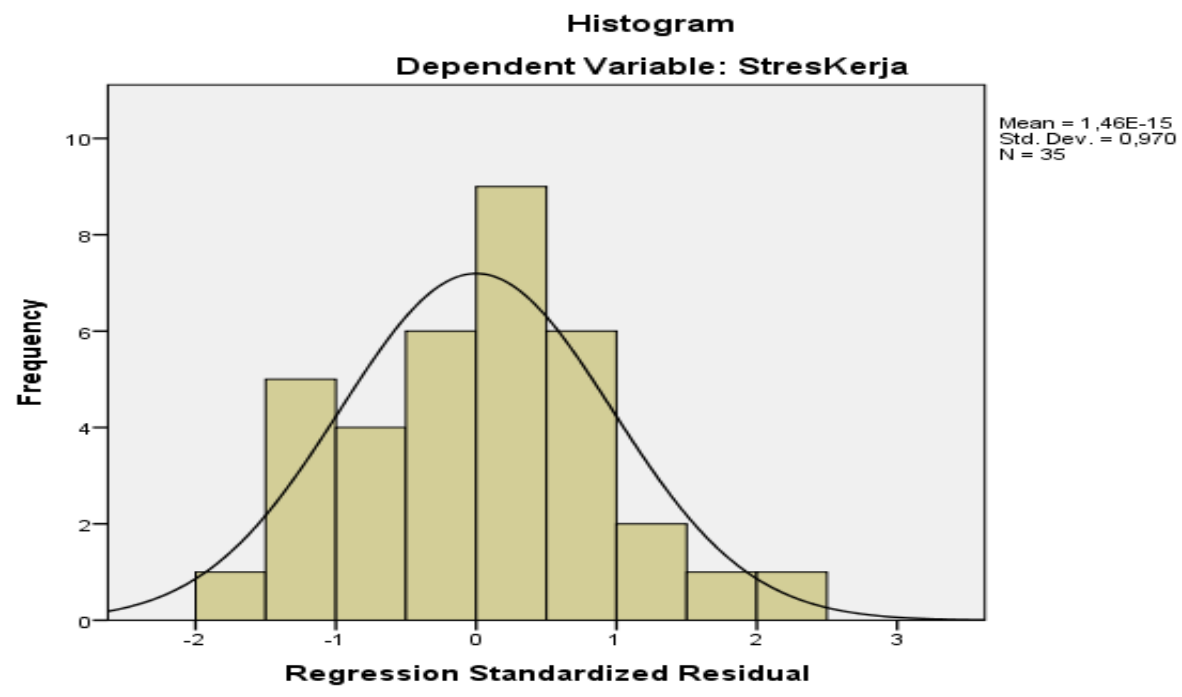

Figure 1. Histogram Normality Test

The histogram graph in Figure 1 shows that the curve graph is symmetrically skewed (U) and neither deviated to the left nor deviated to the right so that it can be stated that the data is normally distributed. In the P-Plot normality graph, it can be seen that the data has spread following the diagonal line. The spread is almost completely close to the diagonal line. This shows that the P-Plot graph is normally distributed.In the P-Plot normality graph above, it can be seen that the data has spread following the diagonal line. The spread is almost completely close to the diagonal line. This shows that the P-Plot graph is normally distributed. Normality test results kolmogorov-smirnov shows that the significant value is 0.977 $>0.05$ thus that the data is normally distributed. Revealing this test has a purpose in measuring whether the regression model found a correlation between the independent variables. The VIF value of the independent variable of leadership style is 1.185 and the workload is 1.185 . The three variables have a value below 10 and a value of tolerance is above 0.1 , namely the independent variable leadership style of 0.844 and workload of 0.844 . So that there are no symptoms of multicollinearity.

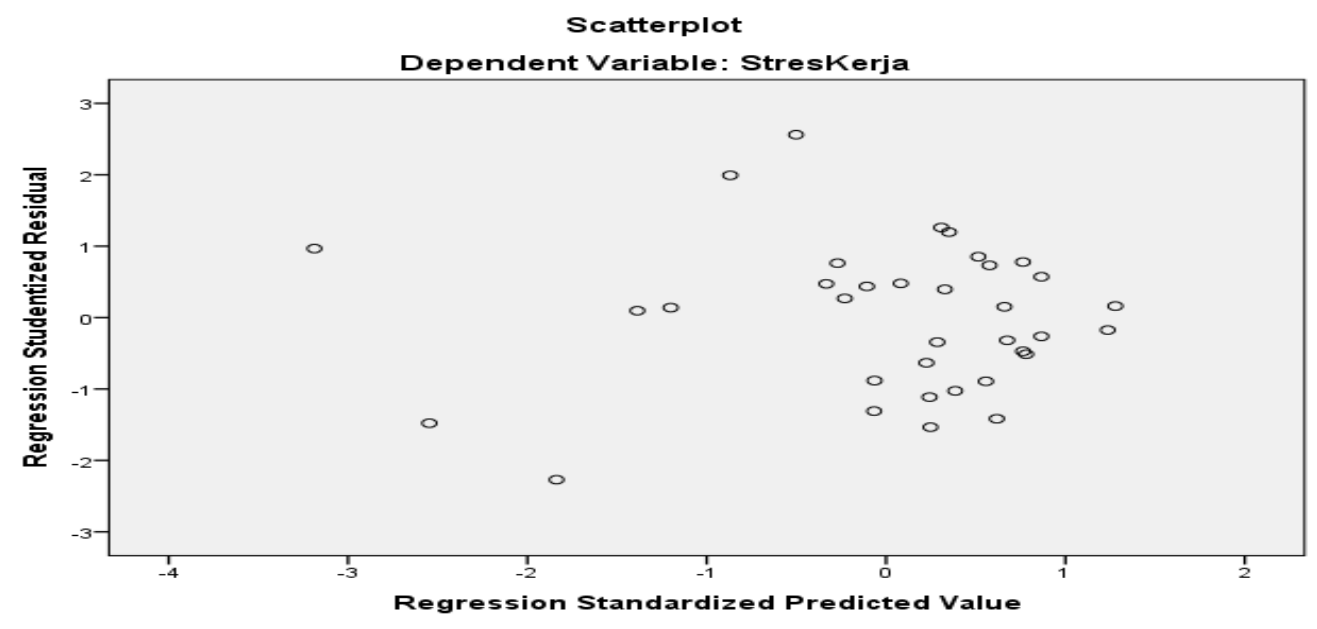

Figure 2. Heteroscedasticity Test

Based on the scatterplot graph, it appears that the spots are scattered with a regular pattern both above and below the number ( 0 ) on the $\mathrm{Y}$ axis and are not clustered in one place, so from the graph above it can be concluded that there is no heteroscedasticity. The meaning of the multiple linear regression equation above is a constant value of -3.725 which indicates that the leadership style and workload variables are considered zero $(0)$ then work stress $(\mathrm{Y})$ is -3.725 . The leadership style regression unit value is 0.400 states that for every $1 \%$ increase in the leadership style variable, work stress $(\mathrm{Y})$ will increase by 0.400 units. The workload regression unit value is 0.497 states that for every $1 \%$ increase in the workload variable, employee performance (Y) will increase by 0.497 units. 
The coefficient of determination of Adjusted R Square aims to calculate the extent to which the model's ability to explain the independent variables. The value of this adjusted $r$ square is 0.802 or $80.2 \%$, which means that the leadership style and workload variables only explain the variation of the work stress variable by $80.2 \%$ and the remaining $19.8 \%$ is influenced by other variables outside of this research variable. The F statistical test generally shows whether all independent variables included in the model have a simultaneous effect on the dependent variable. In this test the result of $F_{\text {statistic }}$ is 64,642 and $F_{\text {table }}$ is 3.29 which means $F_{\text {statistic }}>F_{\text {table }}$ is $64,642>3.29$ with a significant level of $0.000<0.05$ then $\mathrm{H}_{0}$ is rejected and $\mathrm{Ha}$ is accepted so that it can be concluded that leadership style and workload affect work stress at PT Bank Perkreditan Rakyat Buana Agribisnis Saribudolok.

The t-statistic test generally proves the extent to which the influence of an explanatory or dependent variable on an individual is to explain the variation of the independent variable. The leadership style variable has a $t_{\text {statistic }}$ of 5.013 and a $t$-table of 1.69389 which means that $t_{\text {statistic }}>t_{\text {table }}$ is $5.013>1.69389$ with a significant level of $0.000<0.05$, which means $\mathrm{HO}$ is rejected and Ha is accepted, which means that leadership style has a partial and significant effect on work stress at PT Bank Perkreditan Rakyat Buana Agribisnis Saribudolok. The workload variable has a tstatistic value of 7.398 and a table of 1.69389 which means that $t_{\text {statistic }}>t_{\text {table }}$ is $7.398>1.69389$ with a significant level of $0.000<0.05$ which means H0 is rejected and $\mathrm{Ha}$ is accepted which means that the workload has an effect and is partially significant on work stress at PT Bank Perkreditan Rakyat Buana Agribisnis Saribudolok.

\section{Discussion}

The results of partial hypothesis testing show that the value of $t_{\text {statistic }}$ of 5.013 and $t$ table of 1.69389 which means that $t_{\text {statistic }}>t_{\text {table }}$ is $5.013>1.69389$ with a significant level of $0.000<0.05$ which means H0 is rejected and Ha is accepted meaning that leadership style has a positive and partially significant effect on work stress at PT Bank Perkreditan Rakyat Buana Agribisnis Saribudolok. Based on the results obtained, leadership style affects employee work stress which is related to how employees guess a leadership style, whether they like it or not, like it or not. Poor leadership style causes employees to be unproductive and less creative so that it has an impact on achieving a career that employees aspire to so that employees are stressed about their work (Abbas \& Ali, 2021; Leigh et al., 2021; Padauleng et al., 2020). The indicators of philosophical leadership style, leadership attitudes and politics, skills already have a high category, meaning that the leadership style in the company is related to employees, leaders can receive input from employees and leaders become a place for employees to exchange ideas (AlNuaimi et al., 2021; Richard et al., 2019; Stremersch et al., 2021). It can reduce the work stress of employees at PT Bank Perkreditan Rakyat Buana Agribisnis Saribudolok. The cause of work stress can occur due to a bad leadership style and leadership style has a negative effect on work stress (Marín et al., 2019; Tziner et al., 2015). Authoritarian leadership style has a positive and significant effect on work stress, work style and work stress (Alfathan \& Saleh, 2018; Stremersch et al., 2021). democratic leadership has a negative and significant effect on work stress, laissez faire leadership style has a negative and significant effect on work stress. Leadership style affects work stress.

The results of partial hypothesis testing show that the value of $t_{\text {statistic }}$ of 7.398 and $t_{\text {table }}$ of 1.69389 which means that $t_{\text {statistic }}>t_{\text {table }}$ is $7.398>1.69389$ with a significant level of $0.000<0.05$ which means H0 is rejected and $\mathrm{Ha}$ is accepted meaning that the workload has a partial positive effect on work stress at PT Bank Perkreditan Rakyat Buana Agribisnis Saribudolok. Based on the results obtained, the workload greatly affects employee work stress, there is so much work, fulfillment of needs, and in the end it drains energy both physically and cognitively (Charoensukmongkol, 2022; Inegbedion et al., 2020; Ujir et al., 2020). Work stress can occur due to too much workload, commitment to innovation in carrying out tasks, obstacles in carrying out tasks, these greatly affect employee work stress. On workload indicators, namely workload analysis, efficiency, effectiveness already have a high category which means that the application of the number of working hours (Fuadiputra \& Novianti, 2021; Johari et al., 2016; Liu \& Lo, 2018). The number of employees to complete work in the company and the ability to complete tasks in the company are good, it is also affect work stress at PT Bank Perkreditan Rakyat Buana Agribisnis Saribudolok. Workload has an influence on work stress.

The results of simultaneously testing the hypothesis are seen that $F_{\text {statisticis }} 64,642$ and $F_{\text {table }}$ is 3,29 which means that $F_{\text {statistic }}>F_{\text {table }}$ is $64,642>3.29$ with a significant level of $0.000<0.05$ then $\mathrm{H} 0$ is rejected and $\mathrm{Ha}$ is accepted so that it can be concluded that leadership style and workload have a positive and significant effect on Simultaneous work stress at PT Bank Perkreditan Rakyat Buana Agribisnis Saribudolok. The results of this study are in line with research, which states that leadership styles and workloads that are not in accordance with the wishes of employees can cause employees to experience work stress, resulting in less effective work in the office (Bonfim et al., 2021; Esteban et al., 2022; McDonnell et al., 2021). A leadership style that is too demanding of employees can cause employees to feel pressured as well as 
excessive workloads, for example, many working hours and too many work deadlines can affect employee work stress (Chen \& Tserng, 2022; Li et al., 2020; Verstappen et al., 2022).

\section{CONCLUSION}

It can be concluded that leadership style has a positive and partially significant effect on work stress at PT Bank Perkreditan Rakyat Buana Agribusiness Saribudolok. The workload has a positive and partially significant effect on work stress at PT Bank Perkreditan Rakyat Buana Agribusiness Saribudolok. Leadership style and workload have a positive and significant effect simultaneously on work stress at PT Bank Perkreditan Rakyat Buana Agribusiness Saribudolok. The leadership style and workload variables only explain the variation of work stress variables by $80.2 \%$ and the remaining $19.8 \%$ is influenced by other variables outside of this research variable.

\section{REFERENCES}

Abbas, M., \& Ali, R. (2021). Transformational versus transactional leadership styles and project success: A meta-analytic review. European Management Journal, 1. https://doi.org/10.1016/j.emj.2021.10.011.

Abbasi, A. M., Darvishi, E., Rodrigues, M. A., \& Sayehmiri, K. (2022). Gender differences in cognitive performance and psychophysiological responses during noise exposure and different workloads. Applied Acoustics, 189. https://doi.org/10.1016/j.apacoust.2021.108602.

Alfathan, I. H., \& Saleh, A. (2018). Gaya Kepemimpinan dan Intensitas Komunikasi GPPT dengan Efektivitas Kelompok di Sekolah Peternakan Rakyat. Jurnal Sains Komunikasi Dan Pengembangan Masyarakat [JSKPM], 2(3), 289-300. https://doi.org/10.29244/jskpm.2.3.289-300.

AlNuaimi, B. K., Singh, S. K., \& Harney, B. (2021). Unpacking the role of innovation capability: Exploring the impact of leadership style on green procurement via a natural resource-based perspective. Journal of Business Research, 134. https://doi.org/10.1016/j.jbusres.2021.05.026.

Ariyani, D. (2021). Principal's Innovation and Entrepreneurial Leadership to Establish a Positive Learning Environment. European Journal of Educational Research, 10(1), 63-74. https://doi.org/10.12973/eu-jer.10.1.63.

Battisti, S., Agarwal, N., \& Brem, A. (2022). Creating new tech entrepreneurs with digital platforms: Metaorganizations for shared value in data-driven retail ecosystems. Technological Forecasting and Social Change, 175. https://doi.org/10.1016/j.techfore.2021.121392.

Bitkina, O. V., Park, J., \& Kim, H. K. (2021). The ability of eye-tracking metrics to classify and predict the perceived driving workload. International Journal of Industrial Ergonomics, 86. https://doi.org/10.1016/j.ergon.2021.103193.

Bonfim, A. K. S., Passos, I. C. M. de O., Saleh, C. M. R., \& Nogueira, L. de S. (2021). Nursing workload of trauma patients in the emergency room: A prospective cohort study. International Emergency Nursing, 59. https://doi.org/10.1016/j.ienj.2021.101071.

Charoensukmongkol, P. (2022). Supervisor-subordinate guanxi and emotional exhaustion: The moderating effect of supervisor job autonomy and workload levels in organizations. Asia Pacific Management Review, 27(1). https://doi.org/10.1016/j.apmrv.2021.05.001.

Chen, W.-C., \& Tserng, H. P. (2022). Real-time individual workload management at tunnel worksite using wearable heart rate measurement devices. Automation in Construction, 134. https://doi.org/10.1016/j.autcon.2021.104051.

Dang-Pham, D., Kautz, K., Hoang, A.-P., \& Pittayachawan, S. (2022). Identifying information security opinion leaders in organizations: Insights from the theory of social power bases and social network analysis. Computers \& Security, 112. https://doi.org/10.1016/j.cose.2021.102505.

Esteban, R. F. C., Mamani-Benito, O., Chaparro, J. E. T., Lingán-Huamán, S. K., \& Pajares, A. E. (2022). Psychological distress and workload as predictors of satisfaction with life in Peruvian female university professors with a family burden. Heliyon, 8(1). https://doi.org/10.1016/j.heliyon.2021.e08711.

Fazal, M. A. ul, Ferguson, S., \& Saeed, Z. (2022). Investigating cognitive workload in concurrent speech-based information communication. International Journal of Human-Computer Studies, 157. https://doi.org/10.1016/j.ijhcs.2021.102728.

Fuadiputra, I. R., \& Novianti, K. R. (2021). The Effect of Work Autonomy and Workload on Job Satisfaction of Female Workers in the Banking Sector: Mediating the Role of Work Life Balance. The Winners, 21(2), 85-91. https://doi.org/10.21512/tw.v21i2.6908.

Gibbs, D., Odeh, N., Theron, M., \& Harding, C. (2021). Level 1 neonatal nursing staff perceptions of their role: 
A qualitative Framework Analysis study investigating the complex and diverse workload undertaken by nurses in special care baby units. Journal of Neonatal Nursing, 27(4). https://doi.org/10.1016/j.jnn.2020.10.004.

Gishti, E. (Shehi). (2018). Social Partnership in Vocational Education and Training in Albania. European Journal of Education, 1(3), 163-169. https://doi.org/10.26417/ejed.v1i3.p163-169.

Grigoropoulos, J. E. (2019). The Role of Ethics in 21st Century Organization. International Journal of Progressive Education, 15(2), 167-175. https://doi.org/10.29329/ijpe.2019.189.12.

Hasna. (2019). The Effect Of Financial And Non Financial Compensation On Employee Job Satisfaction Of Pt Bank Perkreditan Rakyat (BPR) Modern Express Of Ambon Branch. Russian Journal of Agricultural and Socio-Economic Sciences, 94(10). https://doi.org/10.18551/rjoas.2019-10.05.

Heinbockel, H., Quaedflieg, C. W. E. M., Schneider, T. R., Engel, A. K., \& Schwabe, L. (2021). Stress enhances emotional memory-related theta oscillations in the medial temporal lobe. Neurobiology of Stress, 15. https://doi.org/10.1016/j.ynstr.2021.100383.

Ifeoma Obidile, J. (2018). Revitalization of the Technical and Vocational Education (TVE) Programmes for Youth Empowerment in Nigeria. International Journal of Vocational Education and Training Research, 4(1), 45-47. https://doi.org/10.11648/j.ijvetr.20180401.17.

Indiyaningsih, K. M. H., Murdyastuti, A., \& Puspitaningtyas, Z. (2020). Efeect of human resource competency, work culture and utilization of information technology to performance of employees. International Journal of Scientific and Technology Research, 9(4), 3636-3641. https: //doi.org/10.19184/issrd.v2i1.17468.

Inegbedion, H., Inegbedion, E., Peter, A., \& Harry, L. (2020). Perception of workload balance and employee job satisfaction in work organisations. Heliyon, 6(1). https://doi.org/10.1016/j.heliyon.2020.e03160.

Jain, G., Sharma, N., \& Shrivastava, A. (2021). Enhancing training effectiveness for organizations through blockchain-enabled training effectiveness measurement (BETEM). Journal of Organizational Change Management, 34(2), 439-461. https://doi.org/10.1108/JOCM-10-2020-0303.

Johari, J., Tan, fee Y., \& Tjik, Z. I. (2016). Autonomy, workload, worklife balance and job performance teachers. International Journal for Researcher Development, 7(1), 63-83. https://doi.org/10.1108/MRR-09-2015-0216.

Klatzkin, R. R., Nolan, L. J., \& Kissileff, H. R. (2022). Self-reported emotional eaters consume more food under stress if they experience heightened stress reactivity and emotional relief from stress upon eating. Physiology \& Behavior, 243. https://doi.org/10.1016/j.physbeh.2021.113638.

Leigh, J., Lamont, M., \& Cairncross, G. (2021). Event managers' leadership styles and attitudes towards resourcing volunteer training: Exploring variation and practice implications. Tourism Management Perspectives, 40. https: //doi.org/10.1016/j.tmp.2021.100887.

Li, X., Vaezipour, A., Rakotonirainy, A., Demmel, S., \& Oviedo-Trespalacios, O. (2020). Exploring drivers' mental workload and visual demand while using an in-vehicle HMI for eco-safe driving. Accident Analysis \& Prevention, 146. https://doi.org/10.1016/j.aap.2020.105756.

Liu, H. L., \& Lo, V. hwei. (2018). An integrated model of workload, autonomy, burnout, job satisfaction, and turnover intention among Taiwanese reporters. Asian Journal of Communication, 28(2), 153-169. https: //doi.org/10.1080/01292986.2017.1382544.

Mahriani, E. (2018). Pengaruh Stres Dan Disiplin Kerja Karyawan Terhadap Kepuasan Dan Kinerja Karyawan Pt. Bank Perkreditan Rakyat (Bpr) Mitrathama Arthabuana Di Kabupaten Banjar. AtTaradhi: Jurnal Studi Ekonomi, 9(1). https://doi.org/10.18592/at-taradhi.v9i1.2120.

Marín, M., Rodríguez, Y., Gamboa, E., Ríos, J., Rosas, J., \& Mayta-Tovalino, F. (2019). Level of work stress and factors associated with bruxism in the military crew of the Peruvian Air Force. Medical Journal Armed Forces India, 75(3). https://doi.org/10.1016/j.mjafi.2019.01.001.

McDonnell, A. S., Imberger, K., Poulter, C., \& Cooper, J. M. (2021). The power and sensitivity of four core driver workload measures for benchmarking the distraction potential of new driver vehicle interfaces. Transportation Research Part F: Traffic Psychology and Behaviour. https://doi.org/10.1016/j.trf.2021.09.019.

Neill, M. S., \& Bowen, S. A. (2021). Employee perceptions of ethical listening in U.S. organizations. Public Relations Review, 47(5). https://doi.org/10.1016/j.pubrev.2021.102123.

Ogu, Ntoimo, \& Okonofua. (2017). Perceptions of women on workloads in health facilities and its effect on maternal health care: A multi-site qualitative study in Nigeria. Midwifery, 5. https://doi.org/10.1016/j.midw.2017.08.008.

Oludayo, O. A., Akanbi, C. O., Falola, H. O., \& Aluko, O. A. (2018). Data on perceived excessive workload on faculty members' commitment. Data in Brief, 20. https://doi.org/10.1016/j.dib.2018.08.132.

Padauleng, A. W., Sidin, A. I., \& Ansariadi. (2020). The relationship between leadership style and nurse's 
work motivation with the implementation of patient safety culture in hospital, Bone regency. Enfermería Clínica, 30(6). https://doi.org/10.1016/j.enfcli.2020.06.037.

Purwatiningsih, A., \& Pornamasari, I. R. (2020). Analisis Faktor Yang Mempengaruhi Tingkat Kelancaran Pengembalian Kredit (Studi Kasus Pada PT. BPR Kawan Malang). Jurnal Akuntansi Dan Perpajakan, 6(2). https://doi.org/10.26905/ap.v6i2.5092.

Richard, K., Noujaim, M., Thorndyke, L. E., \& Fischer, M. A. (2019). Preparing Medical Students to Be Physician Leaders: A Leadership Training Program for Students Designed and Led by Students. MedEdPORTAL: The Journal of Teaching and Learning Resources, 15, 10863. https://doi.org/10.15766/mep_2374-8265.10863.

Schaper, S. J., \& Stengel, A. (2022). Emotional stress responsivity of patients with IBS - a systematic review. Journal of Psychosomatic Research, 153. https://doi.org/10.1016/j.jpsychores.2021.110694.

Seo, K., Jordan, E., Woosnam, K. M., Lee, C.-K., \& Lee, E.-J. (2021). Effects of emotional solidarity and tourismrelated stress on residents' quality of life. Tourism Management Perspectives, 40. https://doi.org/10.1016/j.tmp.2021.100874.

Sergeeva, N., \& Kortantamer, D. (2021). Enriching the concept of authentic leadership in project-based organisations through the lens of life-stories and self-identities. International Journal of Project Management, 39(7). https://doi.org/10.1016/j.ijproman.2021.09.001.

Stremersch, S., Camacho, N., Keko, E., \& Wuyts, S. (2021). Grassroots innovation success: The role of selfdetermination and leadership style. International Journal of Research in Marketing. https://doi.org/10.1016/j.ijresmar.2021.10.003.

Sufriadi, D. (2019). Theoretical Review Of The Efficiency Of Leadership Work From The Perspective Role Of The Secretary. Jurnal Apresiasi Ekonomi, 7(2), 139-149. https://doi.org/10.31846/jae.v7i2.211.

Sugiyono. (2017). Metode Penelitian Kuantitatif, Kualitatif, dan R\&D. Alfabeta.

Tziner, A., Rabenu, E., Radomski, R., \& Belkin, A. (2015). Work stress and turnover intentions among hospital physicians: The mediating role of burnout and work satisfaction. Revista de Psicologia Del Trabajo y de Las Organizaciones, 31(3), 207-213. https://doi.org/10.1016/j.rpto.2015.05.001.

Ujir, H., Salleh, S. F., Marzuki, A. S. W., Hashim, H. F., \& Alias, A. A. (2020). Teaching Workload in 21st Century Higher Education Learning Setting. International Journal of Evaluation and Research in Education, 9(1), 221-227.

Verstappen, V. J., Pikaar, E. N., \& Zon, R. G. (2022). Assessing the impact of driver advisory systems on train driver workload, attention allocation and safety performance. Applied Ergonomics, 100. https://doi.org/10.1016/j.apergo.2021.103645.

Zhou, H., Molesworth, B. R. C., Burgess, M., \& Hatfield, J. (2022). The effect of broadband noise on learning and dynamic decision-making and how cognitive workload and sex moderate its effect. Applied Ergonomics, 98. https://doi.org/10.1016/j.apergo.2021.103604 AAA. 